\title{
Benthic scavenger community composition and carrion removal in Arctic and Subarctic fjords
}

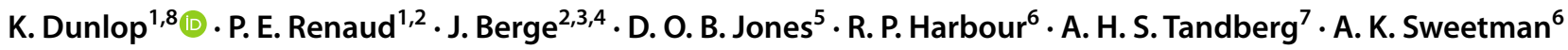

Received: 6 December 2019 / Accepted: 17 November 2020 / Published online: 5 December 2020

(c) The Author(s) 2020

\begin{abstract}
In high latitude coastal regions, benthic scavenger communities are largely composed of invertebrates that play a key role in the cycling of organic matter. Factors including temperature and depth can structure Arctic and Subarctic fjord benthic communities, but the response of scavenging communities to these factors is poorly known. To address this, we compared scavenging fauna in eight fjords with different physical characteristics in Svalbard and northern Norway using time-lapse imagery of scavengers consuming Atlantic herring (Clupea harengus) bait. Fjords influenced by relatively warm Atlantic waters, both in Norway and Svalbard, had high scavenger richness. However, Svalbard fjords with negative bottom temperatures had the lowest species richness and were dominated by lysianassoid amphipods and ophiuroids. In these cold Svalbard fjords, the mean carrion removal rates were almost 20 times higher than mean values noted elsewhere, except in the warm Norwegian fjord Kaldfjorden. Amphipods and ophiuroids quickly reduced the bait to bones (207.6-304.7 g removed per hour $\left(\mathrm{g} \mathrm{h}^{-1}\right)$; mean $\left.290.6 \pm 7.3 \mathrm{~g} \mathrm{~h}^{-1}, n=4\right)$ in cold Svalbard fjords. In the warmer Svalbard fjords, carrion removal rates were low $\left(0-51.5 \mathrm{~g} \mathrm{~h}^{-1}\right.$; mean $\left.14.6 \pm 9.0 \mathrm{~g} \mathrm{~h}^{-1}, n=5\right)$. Carrion removal rates in Kaldfjorden were higher than other Atlantic Water influenced fjords (132.1 and $372.5 \mathrm{~g} \mathrm{~h}^{-1}, n=2$ ) owing to the scavenging activity of Atlantic cod (Gadus morhua). The results demonstrate potential ecosystem responses to warming in Arctic and Subarctic fjords, particularly effects related to range expansion of boreal species.
\end{abstract}

Keywords Arctic fjords $\cdot$ Benthic scavengers $\cdot$ Climate change $\cdot$ Atlantic cod

\section{Introduction}

Scavengers feed on carrion and thus play a major role in nutrient cycling and maintaining ecosystem function in marine habitats (Britton and Morton 1994; King et al. 2007).

Electronic supplementary material The online version of this article (https://doi.org/10.1007/s00300-020-02773-5) contains supplementary material, which is available to authorized users.

\section{K. Dunlop}

katherine.mary.dunlop@hi.no

1 Akvaplan-niva, 9296 Fram Centre, Troms $\varnothing$, Norway

2 University Centre in Svalbard, Longyearbyen, Norway

3 Department of Arctic and Marine Biology, University of Troms $\varnothing$, Troms $\varnothing$, Norway

4 Centre for Autonomous Marine Operations and Systems, Department of Biology, NTNU, Trondheim, Norway

5 National Oceanography Centre, University of Southampton Waterfront Campus, Southampton, UK
In coastal northern high latitude waters, studies have been conducted on the community composition (Legeżyńska et al. 2000; Legeżyńska 2001; Nygård et al. 2012), population dynamics (Nygård et al. 2009, 2010) and feeding ecology (Legeżyńska 2001, 2008; Nygård et al. 2012) of shallow water scavenging amphipods. However, similar knowledge on the complete scavenger guild present in deep Arctic and Subarctic coastal waters remains limited compared to

6 Marine Benthic Ecology, Biogeochemistry and In Situ Technology Research Group, The Lyell Centre for Earth and Marine Science and Technology, Heriot-Watt University, Edinburgh EH14 4AP, UK

7 Department of Natural History, University Museum of Bergen, University of Bergen, P.O. Box 7800, 5020 Bergen, Norway

8 Present Address: Institute of Marine Research, 9007 Troms $\varnothing$, Norway 
other marine ecosystems (i.e. the deep Pacific and Atlantic Oceans or temperate coastal regions). Studies performed in littoral and sub-littoral Svalbard waters, suggest that lysianassoid amphipods are the dominant scavenging group in some fjords (i.e. Rijpfjorden, Hornsund, Adventfjorden and Kongsfjorden) and are readily attracted to bait (Legeżyńska et al. 2000, 2001; Nygård et al. 2009, 2012). Scavenging amphipods are highly mobile and can rapidly locate carrion using highly developed chemoreceptors (Sainte-Marie 1992). A study examining the diets of lysianassoids attracted to baited traps in Kongsfjorden has demonstrated that shallow water amphipods of this superfamily rely less upon scavenging in comparison to deep-water lysianassoid amphipods (Legeżyńska et al. 2000). Arctic scavenging communities from abyssal depths (1500-5000 m) in the Fram Strait were also dominated by scavenging amphipods, in particular, the superfamilies Lysianassoidea and Stegocephaloidea (Klages et al. 2001; Premke et al. 2003, 2006). Lysianassoid amphipods of the genera Anonyx, Orchomenella and Tmetonyx have been caught in baited traps in Malangenfjorden in northern Norway (Christiansen and Diel-Christiansen 1993). In the deep southern Norwegian fjord Sognefjorden, scavenging amphipods attended and fed upon mackerel (Scomber scombrus) carcasses alongside Atlantic hagfish (Myxine glutinosa), pandalid shrimps and squat lobsters (Munida tenuimana) (Sweetman et al. 2014).

Svalbard fjords are influenced by water masses flowing northward from the Norwegian Sea (e.g. Kongsfjorden and Raudfjorden on western Svalbard), southward from the Arctic Ocean (Rijpfjorden in northern Svalbard) and from glacial meltwater (Billefjorden) (Rudels et al. 2000; Cottier et al. 2005). Water flowing northward from the Atlantic Ocean also influences fjords in northern Norway. The origin of the water masses entering the fjord has a substantial influence on the abiotic conditions of the fjords (i.e. temperature, ice coverage and salinity), which structures benthic fjord communities that inhabit these areas (Meyer et al. 2015; Molis et al. 2019). Community structure of both infauna and epifauna has been studied in Arctic fjords and has been linked to the physical characteristics of the habitat (reviewed by Molis et al. 2019). Infaunal community structure varies with the predominant water mass (Włodarska-Kowalczuk et al. 1998) among fjords/regions, but within a fjord, gradients in community structure are often driven by differences in sedimentation (from glaciers and rivers) and food supply (pigment and organic carbon content) along the fjord axes (Włodarska-Kowalczuk et al. 2005, 2012; Renaud et al. 2007). The impacts of glacial disturbance are known to decline towards the fjord mouth and to coincide with an increase in the biomass and species richness of fjord benthic macro- and megafauna (Włodarska-Kowalczuk and Pearson 2004; Włodarska-Kowalczuk et al. 2005; Jones et al. 2007; Kędra et al. 2010). Bottom water oxygen content and organic enrichment are also known to be important factors in structuring soft-bottom benthic communities in deep-basin Subarctic fjords (Tysfjorden, Norway) (Molina et al. 2019). The community composition of the epifaunal megabenthos in two Svalbard fjords (Raudfjorden and Rijpfjorden) appears to be strongly driven by bottom water temperature and depth (Meyer et al. 2015). A broader analysis of Arctic epifaunal communities suggests that structure is also influenced by different factors on different spatial scales, from broad spatial (depth, latitude) parameters on the largest scale to habitat (water mass, substrate) and food supply characteristics on a smaller scale (Roy et al. 2014). The composition of shallow water amphipod communities and their scavenging activities in the coastal Arctic have been related to depth, hydrological conditions, sedimentation regime, bottom type, season, the presence of sea-ice and food accessibility (Legeżyńska 2001; Nygård et al. 2012).

In addition to environmental factors, the presence (or absence) of competitors and predators can also affect the distribution of benthic scavenger communities. New potential competitors and predators are expanding their distribution range into the rapidly warming Arctic sea (Renaud et al. 2015) and impacts on benthic communities have begun to be documented (Beuchel et al. 2006; Kortsch et al. 2012). The distribution of Atlantic cod (Gadus morhua) is dependent on water temperature (Sunby and Nakken 2008), and recent rapid climatic warming in the Arctic has also led to an expansion of Atlantic cod (and other demersal fish species) on the western coast of Svalbard since 2006 (Olsen et al. 2009; Renaud et al. 2012; Berge et al. 2015). Increased abundance and distribution of Atlantic cod may be responsible for the displacement and local extinction of native Arctic benthic and bentho-pelagic fish species (Fossheim et al. 2015) and to exert a major effect on both benthic and pelagic biological interactions (Renaud et al. 2012).

Scavenger communities play an integral role in the removal and recycling of carrion in many marine environments, but knowledge is limited on the full composition of marine scavenger communities in coastal Arctic regions and the abiotic factors shaping these communities. In addition, since rapidly warming Arctic temperatures can impact scavenger biodiversity and their ecosystem function, it is important to understand the connections between fjord temperature and scavenging fauna. The objectives of this study were, therefore, to investigate scavenger community composition and the role of scavengers in carrion removal in Arctic fjords and the effects of fjord abiotic factors. A baited, free-fall lander with an underwater camera system was used to study scavenger communities in fjords that experience different hydrological and environmental conditions. In the light of previous results that showed that epifaunal communities in Svalbard fjords were affected by fjord temperature (Meyer et al. 2015), it was hypothesized that scavenging 
community composition and their role in carrion removal will be determined by temperature. It was also hypothesized that the composition of scavenger communities observed in the fjords will be impacted by the presence of boreal Atlantic cod.

\section{Materials and methods}

\section{Site description}

The scavenging fauna and rate of carrion removal was studied using an autonomous baited camera lander in two fjords on the northern Norwegian mainland, and six Svalbard fjords; Isfjorden, Billefjorden, Kongsfjorden, Raudfjorden, Smeerenburgfjorden and Rijpfjorden. Fjords on the mainland (Kaldfjorden and Vengsøyfjorden) and the western coast of Svalbard (Kongsfjorden, Raudfjorden, Smeerenburgfjorden and Isfjorden) are influenced by relatively warm Atlantic Water from the West Spitsbergen Current (WSC) (Svensen et al. 2002; Cottier et al. 2005; Jones et al. 2020) and are herein referred to as "warm Norwegian fjords" and "warm Svalbard fjords". Bottom water temperatures were recorded at each site from a single SeaBird SBE 911plus CTD deployment (except in Vengs $\varnothing y$ fjorden where triplicate ctd measurements were available) (Kaldfjorden $=6.8{ }^{\circ} \mathrm{C}$, Vengs $\varnothing$ yfjorden $=7.1{ }^{\circ} \mathrm{C} \pm 0.1$ (mean $\pm \mathrm{SE}, n=3$ ), Kongsfjorden $=2.5^{\circ} \mathrm{C}$, Raudfjorden $=-0.5^{\circ} \mathrm{C}$, Smeerenburgfjorden $=3.5^{\circ} \mathrm{C}$ and Isfjorden $=0.5^{\circ} \mathrm{C}$ ). Billefjorden, a fjord located in the innermost part of Isfjorden, is influenced by an influx of winter-formed cold and dense glacial meltwater that is retained by the fjord sill. This causes the bottom water temperatures to drop to as low as $-2{ }^{\circ} \mathrm{C}$ (Walkusz et al. 2003). Rijpfjorden in northeast Svalbard is influenced by cold water from the Arctic Ocean for most of the year and covered by fast ice in the winter (Walkusz et al. 2009; Hop et al. 2019). A mean bottom water temperature of $-1.9^{\circ} \mathrm{C} \pm 0.1$ (mean $\pm \mathrm{SE}, n=3$ ) was recorded at Rijpfjorden. Billefjorden and Rijpfjorden are herein referred to as "cold Svalbard fjords". Site locations, depth, temperature and salinity are detailed in Fig. 1 and Online Resource 1.

\section{Scavenger lander deployments}

Time-lapse images of scavenging fauna feeding on Atlantic herring (Clupea harengus) carcasses at the seafloor were captured using an autonomous lander platform (KC Denmark), mounted with an Ocean Imaging Systems DSC24000 deep-sea camera. The camera used was a Nikon 7100 digital single lens reflex camera set to ISO 200, 1/25 s exposure and f-stop 8 , accompanied by two strobe lights. The camera system was set to take an image every 2 min during each deployment. Before each deployment the lander was baited with 10 freshly thawed Atlantic herring weighing $314 \mathrm{~g}( \pm 19 \mathrm{~g}), n=10$. Atlantic herring was used for its strong and oily scent, which is known to effectively attract scavengers (Schmid et al. 2017). Herring carcasses were placed inside a mesh bait bag (mesh size $1.5 \mathrm{~cm}$ ) that was secured on to a $0.25 \mathrm{~m}^{2}$ rectangular bait plate placed $150 \mathrm{~cm}$ directly below the camera lens (Fig. 2). The use of the mesh bag prevented scavengers from removing the bait from the camera field of view and allowed scavengers to be observed feeding on the bait throughout the deployment. Svalbard lander deployments were conducted during the day and night between the 8th and 18th of August 2017 from the RV Helmer Hanssen (UiT, The Arctic University of Norway). Lander deployments were conducted across a range of depths from $145 \mathrm{~m}$ in Smeerenburgfjorden to $360 \mathrm{~m}$ water depth in Kongsfjorden. A single camera lander deployment was made in each fjord except Rijpfjorden (3 replicates) (Online Resource 1). Lander deployments were also made in the warm Norwegian fjords from the RV Johan Hjort (Institute of Marine Research, Norway) between the 30th of November and the 2nd of December 2017. Camera lander deployments in Vengsøyfjorden were made at a water depth of $275 \mathrm{~m}( \pm 2 \mathrm{~m}, n=3)$, and in Kaldfjorden at a depth of $171.5 \mathrm{~m}( \pm 5 \mathrm{~m}, n=2)$ (Online Resource 1). The lander was deployed onto relatively flat seabed in each fjord basin. However, as the geomorphology of each study fjord varied it was only possible to standardize depth as much as possible. The duration of deployments varied from $26 \mathrm{~h} 11 \mathrm{~min}$ (Kongsfjorden) to $7 \mathrm{~h}$ and $7 \mathrm{~min}$ (Smeerenburgfjorden). Prior to each lander deployment, sensor-based water conductivity, temperature $\left({ }^{\circ} \mathrm{C}\right)$ and depth $(\mathrm{m})$ data were collected. Immediately following each lander recovery, scavenging lysianassoid amphipods that remained on the lander bait plate were removed and preserved in $4 \%$ buffered formaldehyde seawater. Remaining herring carcass fragments were removed, dissected to collect scavengers buried in the flesh, blotted dry and weighed to determine the weight of the herring mass removed by the scavengers.

\section{Demersal fish trawls}

Demersal trawls were made in all Svalbard fjords, except Billefjorden, from the RV Helmer Hanssen. Trawling was at a speed of 3 knots with a Campelen trawl (opening of $1.7 \mathrm{~m}$ ) and was conducted on the same date as the lander deployments in the Svalbard fjords (trawl details are reported in full in Online Resource 2). Trawl distances ranged between 0.9 and $2.2 \mathrm{~km}$ and in all cases were less than $5 \mathrm{~km}$ from the lander positions. Demersal trawls in Vengsøyfjorden $(n=2)$ and in Kaldfjorden $(n=1)$ were made on the 2nd and 3rd of April 2019 from the RV Helmer Hanssen and each trawl was 


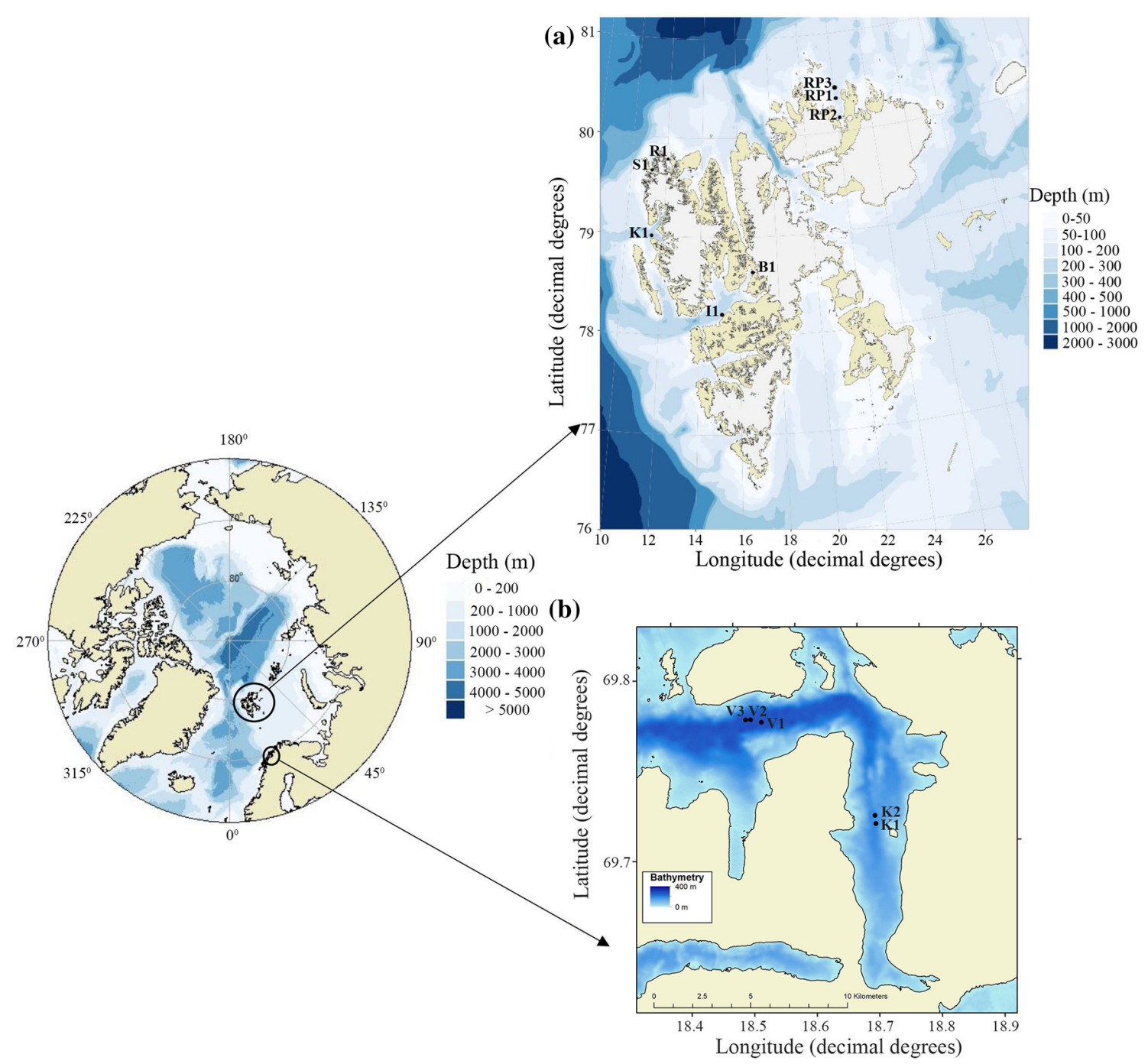

Fig. 1 Camera lander deployment sites in a Kongsfjorden (K1), Raudfjorden (R1), Rijpfjorden (Rp1, Rp2, Rp3), Smeerenburgfjorden (S1), Isfjorden (I1), Billefjorden (B1) and b Vengsøyfjorden (V1, V2, V3) and Kaldfjorden (K1, K2)

over a distance of $1 \mathrm{~km}$, at a speed of 3 knots and in close proximity $(>1 \mathrm{~km})$ to the lander positions.

\section{Image and data analysis}

Images from all 13 lander deployments were viewed in Adobe Photoshop CC 2018. Individuals on the bait plate were considered as scavengers and were identified to the lowest taxonomic level. The number of individuals from each species or taxon were counted for the first $7 \mathrm{~h}$ of each lander deployment. This duration corresponded to the shortest lander deployment (in Smeerenburgfjorden). A semi-automated counting tool, as described in Beuchel et al. (2010), was used to quantify individual amphipods. The technique worked for images where individual amphipods were well separated (i.e. in images recorded in Kongsfjorden and early in the lander deployments in Rijpfjorden and Billefjorden) where the algorithm could distinguish among individual animals. However, in images with dense aggregations of amphipods, the manual Count Tool (Adobe Photoshop CC 2018) was used to annotate images. The herring flesh was consumed as the deployment advanced and showed that some amphipods had been inside and under the flesh and masked during counting. Therefore, amphipod counts represent a minimum abundance. All amphipods in the images were considered as Lysianassoidea based on specimen identification.

The maximum number of scavengers observed at the bait $\left(\operatorname{Max}_{N}\right)$, the time between the arrival of the lander on the seafloor and the arrival of the first scavenger $\left(t_{\text {arrival }}\right)$ are recognized proxies of scavenger abundance (Willis and Babcock 2000; Yeh and Drazen 2009; Langlois et al. 2018). Mean $\operatorname{Max}_{\mathrm{N}}$ and $t_{\text {arrival }}$ values are written \pm standard error in the results, unless otherwise stated. These parameters were 

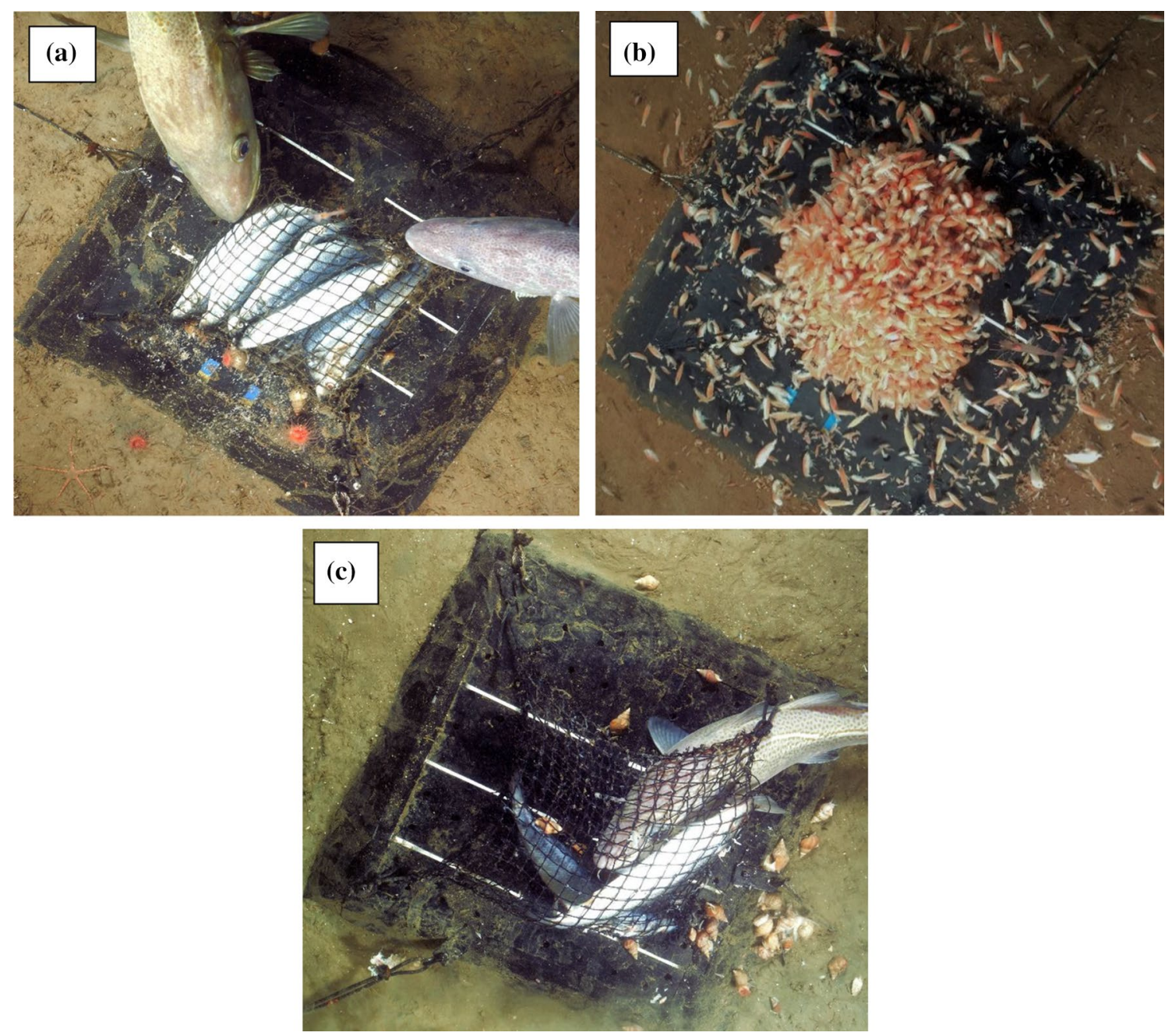

Fig. 2 Lander images of a Atlantic cod (Gadus morhua) investigating the Atlantic herring bait (Clupea harengus) in Kongsfjorden, Svalbard, b A lysianassoid amphipod swarm feeding on herring bait

calculated for each deployment. Scavenging rates were calculated by dividing the change in the weight of the herring bait (if any bait remained on the bait plate upon retrieval) by the deployment duration. However, if all the bait flesh was consumed before the end of the deployment, the scavenging rate was calculated by dividing the bait weight at the beginning of the deployment (minus the skeleton weight at the end) by the time it took for the bait to be completely removed (as observed in the sequence of images).

\section{Statistical analysis}

Scavenger assemblage data between fjords were analysed using the statistical package PRIMER-E v7 (Clarke and Gorley 2015) using $\operatorname{Max}_{\mathrm{N}}$ as a proxy for abundance. For each fjord, the total number of fauna, species richness, Shannon diversity (log base e) and the Pielou evenness index were in Rijpfjorden, Svalbard and c Atlantic cod removing herring bait in Kaldfjorden, Troms, Norway

calculated for scavenger communities. Multivariate analysis was performed using Bray-Curtis dissimilarity coefficients on fourth-root transformed data (transformed to reduce the right skew of the data). A principal coordinates analysis (PCoA) was used to visually examine how fjord depth, temperature, salinity and Atlantic cod abundance (from demersal trawls) structured scavenger assemblage composition in the different fjords. Distance-based linear modelling (DISTLM) analysis was used to examine the relationship between scavenger communities and environmental predictors. Further multivariate analysis was performed in PRIMER-E to examine whether there were differences in scavenger community composition between fjords that were seen to be separated in the PCoA analysis. A univariate statistical analysis was performed on bait consumption rates using the software package R (version 3.3.2; R Core Team 2016). Data on the bait consumption rate did not meet the statistical parametric 
assumptions and thus a non-parametric Kruskal-Wallis test was used to analyse the effect of the fjord temperature on scavenging rates.

\section{Results}

\section{Atlantic cod abundances}

Atlantic cod was a prominent species in the trawl catches in all fjords influenced by Atlantic Water (warm Norwegian and Svalbard fjords). The highest cod abundances were recorded in Raudfjorden and Kongsfjorden (mean 15,000 and 6000 individuals $\mathrm{km}^{2}$, respectively). Cod were also present in other fjords, but in lower numbers (between 1188 and 4250 individuals $\mathrm{km}^{2}$ ). In Rijpfjorden, which is dominated by cold water masses, Atlantic cod were not caught (Online Resource 2).

\section{Scavenger community composition}

Thirty-two scavenger taxa were identified from 13 baited lander deployments in the 8 study fjords (Table 1). At least 16 of these taxa were attracted to the bait in the warm Svalbard fjords including several fish (G. morhua; Hippoglossoides platessoides and Raja radiata) and crustaceans taxa (Hyas araneus, Pandalus sp. and Pagurus pubescens) (Fig. 2a, Table 1). Three taxa were attracted to the bait in Raudfjorden, which was lower compared to the 6 to 11 taxa observed in the other warm Svalbard and warm Norwegian fjord deployments (Table 1). The abundance of scavengers was highest in Kongsfjorden, compared to the other warm Svalbard fjords, and reached a $\operatorname{Max}_{\mathrm{N}}$ of 242 near the end of the lander deployment (Fig. 3a). Shrimp of the genus Pandalus were the first scavengers to arrive in deployments in the warm Svalbard fjords, arriving after 2 to $8 \mathrm{~min}$ in Kongsfjorden, Smeerenburgfjorden and Isfjorden and

Table 1 Scavenger species observed at the lander bait in each deployment site and corresponding maximum abundance $\left(\operatorname{Max}_{\mathrm{N}}\right)$

\begin{tabular}{|c|c|c|c|c|c|c|c|c|}
\hline Scavenger Species & Kongsfjorden & Raudfjorden & $\begin{array}{l}\text { Smeer- } \\
\text { enburgf- } \\
\text { jorden }\end{array}$ & Isfjorden & $\begin{array}{l}\text { Veng- } \\
\text { søyf- } \\
\text { jorden }\end{array}$ & Kaldfjorden & Billefjorden & Rijpfjorden \\
\hline Ophiura albida & 0 & 0 & 0 & 0 & 1 & 1 & 0 & 0 \\
\hline Ophiopleura borealis & 0 & 0 & 0 & 0 & 0 & 0 & 0 & 73 \\
\hline Ophiura sarsii & 2 & 0 & 6 & 0 & 0 & 0 & 0 & 0 \\
\hline Ophiocten sericeum & 0 & 0 & 0 & 0 & 0 & 0 & 52 & 0 \\
\hline $\begin{array}{l}\text { Amphipods(Anonyx nugax, Anonyx } \\
\text { makarovi, Socarnes bidenticulatus, } \\
\text { Tmetonyx sp., Centromedon productus, } \\
\text { Onisimus affinis) }\end{array}$ & 0 & 0 & 0 & 0 & 0 & 0 & 164 & 1160 \\
\hline $\begin{array}{l}\text { Amphipods (Anonyx lilljeborgi, Scope- } \\
\text { locheirus crenatus, Tryphosidae ind sp. } \\
\text { A, Tryphosidae ind sp. B) }\end{array}$ & 0 & 0 & 0 & 0 & 0 & 65 & 0 & 0 \\
\hline Amphipods (unidentified) & 242 & 0 & 0 & 0 & 0 & 0 & 0 & 0 \\
\hline Gadus morhua & 2 & 0 & 0 & 1 & 2 & 4 & 0 & 0 \\
\hline Hippoglossoides platessoides & 1 & 0 & 0 & 1 & 0 & 0 & 0 & 0 \\
\hline Raja radiata & 1 & 0 & 0 & 0 & 0 & 0 & 0 & 0 \\
\hline Brosme brosme & 0 & 0 & 0 & 0 & 1 & 0 & 0 & 0 \\
\hline Liparis sp. & 0 & 0 & 0 & 1 & 0 & 0 & 0 & 0 \\
\hline Boreogadus saida & 0 & 0 & 0 & 0 & 0 & 0 & 2 & 1 \\
\hline Pandalus sp. & 9 & 25 & 30 & 6 & 1 & 1 & 0 & 2 \\
\hline Hyas araneus & 0 & 2 & 2 & 0 & 0 & 0 & 0 & 0 \\
\hline Pagurus pubescens & 0 & 0 & 2 & 0 & 0 & 0 & 0 & 0 \\
\hline Mysida sp. & 8 & 0 & 2 & 4 & 0 & 0 & 0 & 0 \\
\hline Buccinum undatum & 1 & 0 & 5 & 0 & 0 & 38 & 0 & 0 \\
\hline Prosobranch & 13 & 0 & 0 & 0 & 0 & 0 & 0 & 0 \\
\hline Nemertean & 5 & 1 & 0 & 2 & 1 & 8 & 0 & 0 \\
\hline Urasterias lincki & 0 & 0 & 0 & 0 & 0 & 0 & 0 & 1 \\
\hline Chaetognatha sp. & 1 & 0 & 0 & 0 & 0 & 0 & 0 & 0 \\
\hline Polychaeta errantia & 0 & 0 & 0 & 4 & 0 & 0 & 0 & 0 \\
\hline Polycirrus arcticus & 0 & 0 & 0 & 1 & 0 & 0 & 3 & 0 \\
\hline
\end{tabular}



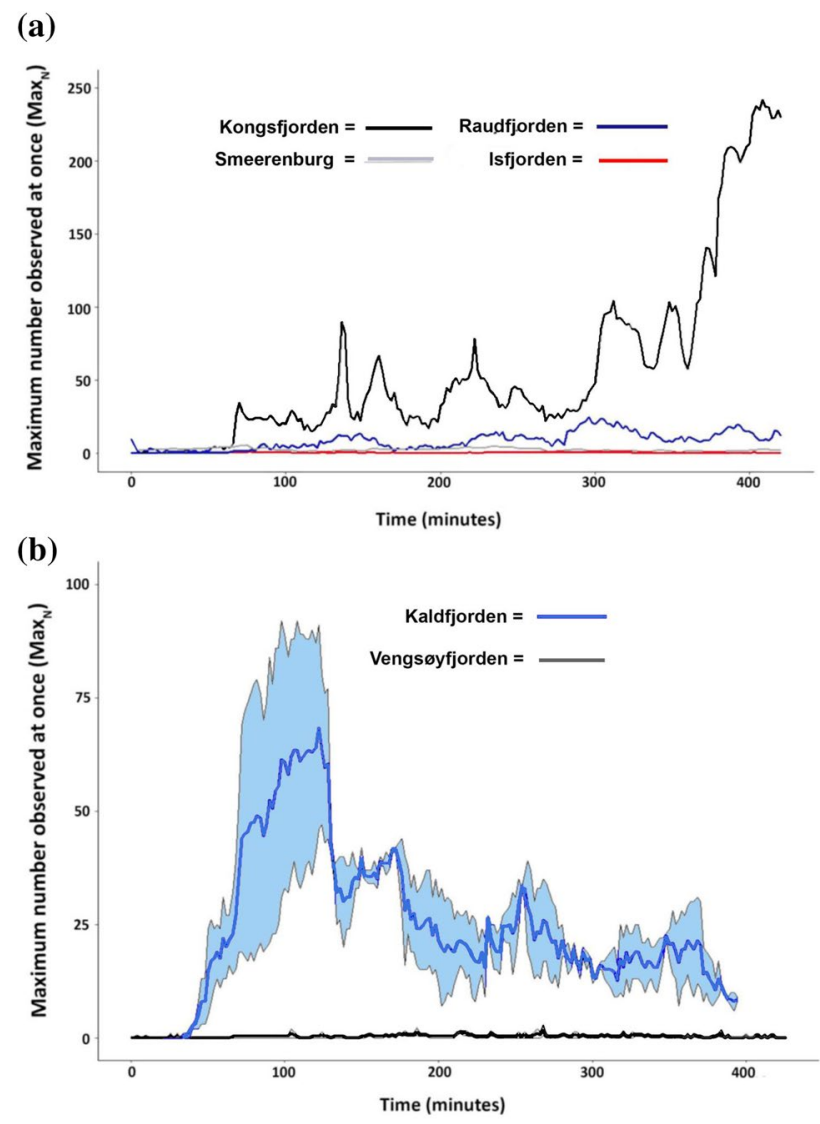

Fig. 3 Mean maximum number $( \pm \mathrm{SE})$ of the total scavengers observed in a Kongsfjorden (black line), Raudfjorden (blue line), Smeerenburgfjorden (grey line) and Isfjorden (red line), and b Kaldfjorden (blue line $($ mean \pm S.E.)) and Vengsøyfjorden (black line $($ mean \pm S.E. $))$

after 64 min in Raudfjorden and reached a mean $\operatorname{Max}_{\mathrm{N}}$ of $17.5 \pm 5.9$ individuals $(n=4)$ (Table 1$)$. Aggregations of lysianassoid amphipods arrived at the bait in Kongsfjorden but appeared to have a limited role in carrion consumption based on the low amount of herring consumed. At least 7 scavenger taxa were attracted to the bait in both the warm Norwegian fjords (Table 1). Buccinum undatum and lysianassoid amphipods dominated in Kaldfjorden, and both taxa arrived after approximately $40 \mathrm{~min}$. B. undatum reached a mean peak of $36.5 \pm 1.5$ individuals at $193 \pm 27 \min (n=2)$ and lysianassoid amphipods peaked at a $\operatorname{Max}_{\mathrm{N}}$ of $40.5 \pm 24.5$ individuals at $94.5 \pm 27.5 \mathrm{~min}(n=2)$ (Fig. $3 b)$. Lysianassoid amphipod aggregations arrived at the bait after 26 and 30 min and included the species; Scopelocheirus crenatus, Anonyx lilljeborgi and 2 species from the genus Tryphosidae (identified from the amphipod samples). The $\mathrm{Max}_{\mathrm{N}}$ of Atlantic cod was highest in Kaldfjorden and reached a mean of $3.5 \pm 0.5$ individuals $(n=2)$ (Fig. 2c). Scavenger abundances in Vengsøyfjorden were the lowest of all fjords with a mean total $\mathrm{Max}_{\mathrm{N}}$ of $3.3 \pm 0.3$ individuals $(n=3)$ and a mean $t_{\text {arrival }}$

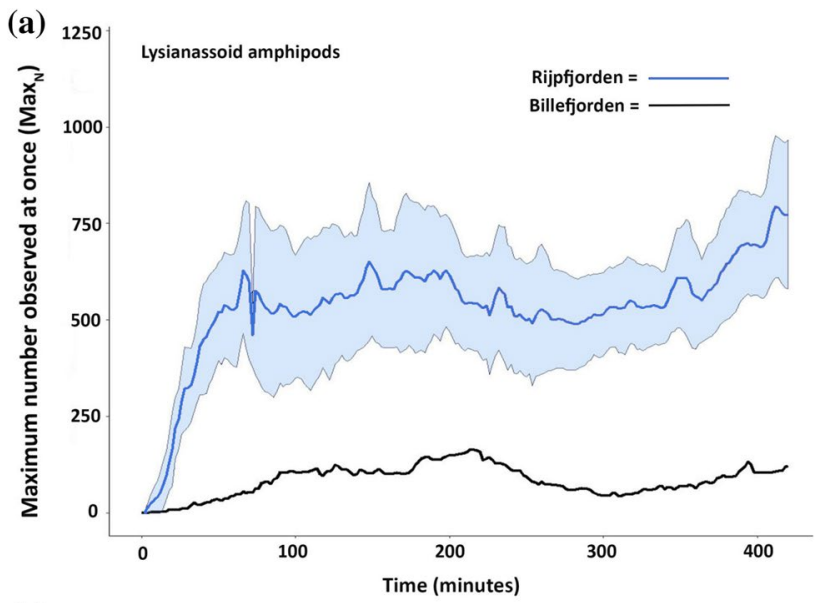

(b)

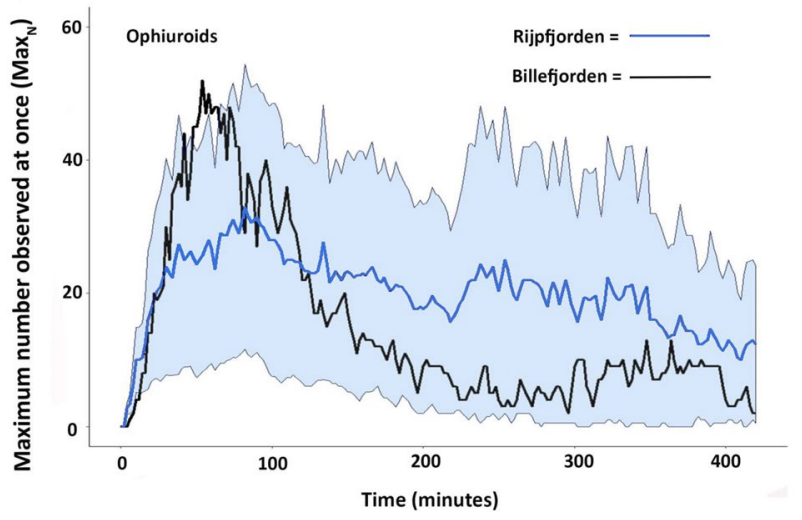

Fig. 4 Mean maximum number $( \pm \mathrm{SE})$ of a lysianassoid amphipod and $\mathbf{b}$ ophiuroids observed at any one time during lander deployments $\left(\mathrm{Max}_{N}\right)$ in Rijpfjorden (blue line $(m e a n \pm$ S.E. $)$ ) and Billefjorden (black line)

of $113( \pm 53.8)$ minutes (Fig. 3b). Scavenger communities in Vengsøyfjorden were comprised of G. morhua, Brosme brosme, Pandalus sp., Ophiura albida and a Nemertean worm (Table 1).

In the cold Svalbard fjords lysianassoid amphipods and ophiuroids (Ophiocten sericeum and Ophiopleura borealis) dominated the scavenging taxa in all deployments (Fig. 2b). In all three Rijpfjorden deployments, O. borealis and lysianassoid amphipods arrived within minutes of the lander reaching the sea floor $\left(t_{\text {arrival }}, 7.3 \pm 3.3 \mathrm{~min}\right.$ and $13.3 \pm 5.9 \mathrm{~min}, n=3$ ) (Fig. 4a, b). Lysianassoid amphipods identified at the bait in Rijpfjorden included the taxa; Onisimus affinis, Anonyx nugax, Anonyx makarovi, Socarnes bidenticulatus, Centromedon productus and Tmetonyx $\mathrm{sp}$. (identified from the amphipod samples). O. borealis numbers peaked earlier than the amphipods with numbers reaching a peak $\mathrm{Max}_{\mathrm{N}}$ of 26 individuals in $60 \mathrm{~min}$ in deployment 1 and 73 individuals in $56 \mathrm{~min}$ in deployment 2. However, only a single $O$. borealis arrived (after $14 \mathrm{~min}$ ) at the bait in the final Rijpfjorden deployment. In all Rijpfjorden 
deployments, lysianassoid amphipod numbers continued to increase with time, peaking at a $\operatorname{Max}_{\mathrm{N}}$ of $817.7 \pm 175.0$ individuals $(n=3)$ after $416 \pm 4$ min. Lysianassoid amphipods and $O$. sericeum were the first taxa to arrive at the bait in Billefjorden ( $t_{\text {arrival }} ; 6$ and 8 min respectively) after the lander reached the seafloor. Amphipod numbers increased to a peak of $\mathrm{Max}_{\mathrm{N}}$ of 164 individuals at $216 \mathrm{~min}$ and $O$. sericeum to a Max $\mathrm{N}_{\mathrm{N}}$ of 52 individuals at $72 \mathrm{~min}$ (Fig. 4a, b). In deployments in both cold Svalbard fjords, ophiuroids moved off the bait plate to form aggregations on the adjacent sediments as lysianassoid amphipod numbers and feeding activity increased. In addition to lysianassoid amphipods and the 2 ophiuroid species, 4 other scavenger taxa were attracted to the bait in the cold Svalbard fjords (Boreogadus saida, Pandalus sp., Urasterias lincki and Polycirrus arcticus). The number of taxa and evenness index were, in general, lower in the cold Svalbard fjords compared to the other six fjords studied (Table 2).

In Kongsfjorden and Raudfjorden herring carcasses were consumed at $32.3 \mathrm{~g} \mathrm{~h}^{-1}$ and $51.5 \mathrm{~g} \mathrm{~h}^{-1}$ but in Smeerenburgfjorden, Isfjorden and Vengsøyfjorden almost no scavenging of the herring bait occurred ( $0-2 \mathrm{~g}$ consumed $\left.\mathrm{h}^{-1}\right)$ (Fig. 5). Herring carcasses were, however, rapidly consumed by ophiuroids and lysianassoid amphipods in Rijpfjorden $\left(284.5 \pm 7.4 \mathrm{~g} \mathrm{~h}^{-1}, n=3\right)$ and Billefjorden (207.6 $\mathrm{g} \mathrm{h}^{-1}$, $n=1$ ) (Fig. 5). The mean scavenging rates in the cold Svalbard fjords were significantly higher compared to rates in the other six fjords studied $\left(55.1 \pm 38.8 \mathrm{~g} \mathrm{~h}^{-1}, n=10\right)$ (Kruskal-Wallis test, $H_{2}=8.1, p=0.02$ ). Carrion removal rates in the cold Svalbard fjords were 19.9 times higher than in Kongsfjorden, Raudfjorden, Smeerenburgfjorden, Isfjorden and Vengsøyfjorden where rates were almost zero to $51.5 \mathrm{~g} \mathrm{~h}^{-1}$ (mean $14.6 \pm 9.0 \mathrm{~g} \mathrm{~h}^{-1}$ ). Carrion removal rates in Kaldfjorden (132.1 and $372.5 \mathrm{~g} \mathrm{~h}^{-1}$ ) were, however, higher than in the other warm Svalbard and Norwegian fjords and more similar to the scavenging rates observed in the cold Svalbard fjords owing to the scavenging activity of Atlantic cod (Fig. 5).

Table 2 Number of species, species diversity (Shannon-Wiener Index) and evenness (Pielou Index) recorded in each fjord

\begin{tabular}{llll}
\hline Fjord & $\begin{array}{l}\text { Number of } \\
\text { taxa }\end{array}$ & $\begin{array}{l}\text { Species diversity } \\
\text { (Shannon-Wiener) }\end{array}$ & $\begin{array}{l}\text { Evenness } \\
\text { (Pielou } \\
\text { Index) }\end{array}$ \\
\hline Kongsfjorden & 11 & 0.628 & 0.262 \\
Raudfjorden & 3 & 0.409 & 0.372 \\
Smeerenburg & 6 & 1.516 & 0.729 \\
Isfjorden & 8 & 1.834 & 0.882 \\
Billefjorden & 4 & 0.663 & 0.478 \\
Rijpfjorden & 5 & 0.187 & 0.213 \\
Kaldfjorden & 6 & 0.868 & 0.606 \\
Vengsøyfjorden & 5 & 1.629 & 0.987 \\
\hline
\end{tabular}

The composition of scavenger communities showed a clear separation in the PCoA plot between the warm Svalbard and Norwegian fjords and the cold Svalbard fjords (Fig. 6). The PCoA cumulatively explained $63.8 \%$ of the variation in the scavenger communities, with temperature at the seafloor, cod abundance and salinity identified as major drivers structuring scavenger community composition. The multivariate regression analysis using DISTLM indicated that the predictor variables, fjord temperature, cod abundance and salinity, best explained the total variation of the scavenger community composition (Table 3 ). Fjord temperature explained the

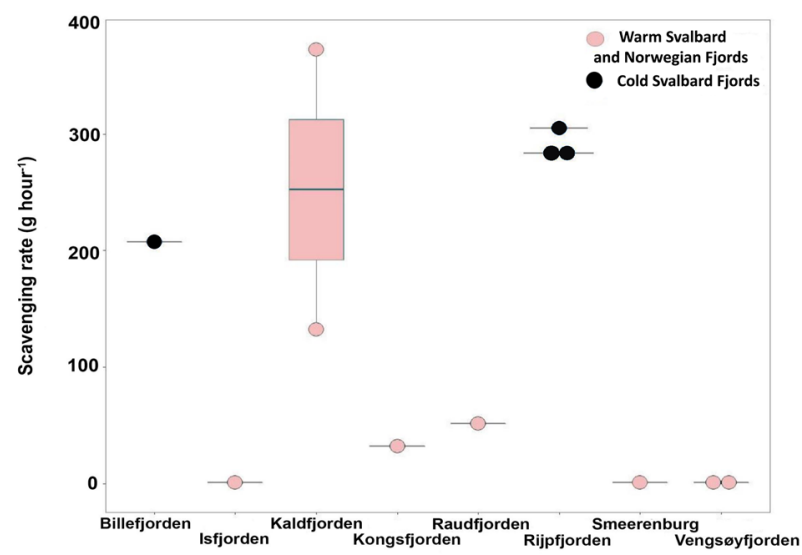

Fig. 5 Wet weight consumption rates $( \pm S E)$ of herring carcasses in the six warm Svalbard and Norwegian fjords and two cold Svalbard fjords

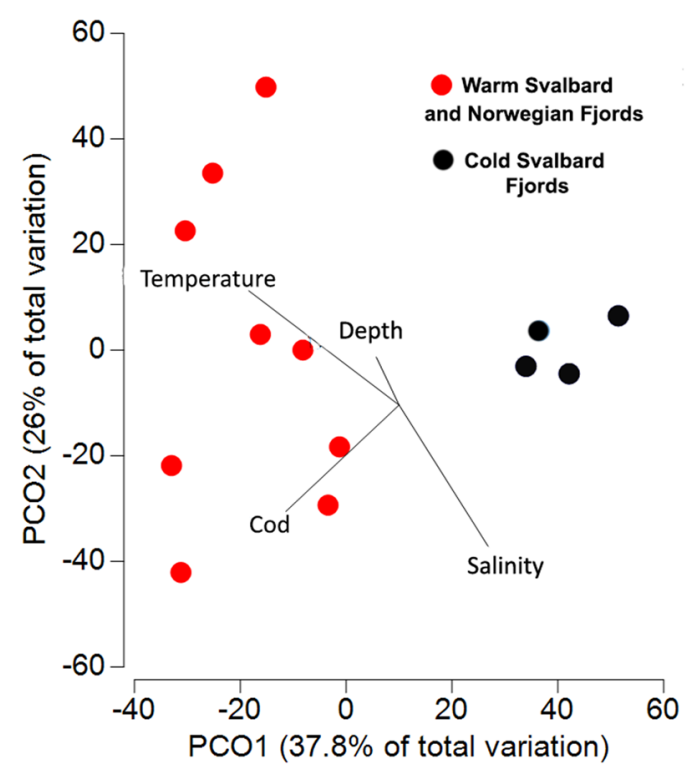

Fig. 6 A principal coordinates analysis ordination of sampled scavenger community composition in warm Svalbard and Norwegian fjords and cold Svalbard fjords 
Table 3 DISTLM modelling results to determine the correlations between scavenger community composition and the environmental variables; Temperature, Cod Abundance, Salinity and Depth

\begin{tabular}{llllllll}
\hline Variable & $R^{2}$ & SS (trace) & Pseudo- $F$ & $p$ & Proportion & Cumulative & $\begin{array}{l}\text { Residual } \\
\text { degrees of } \\
\text { freedom }\end{array}$ \\
\hline Temperature & 0.271 & 7969.4 & 4.089 & 0.003 & 0.271 & 0.271 & 11 \\
Cod Abundance & 0.441 & 4989.3 & 3.033 & 0.018 & 0.170 & 0.441 & 10 \\
Salinity & 0.549 & 3196.9 & 2.171 & 0.044 & 0.109 & 0.549 & 9 \\
Depth & 0.622 & 2127.6 & 1.530 & 0.187 & 0.072 & 0.622 & 8 \\
\hline
\end{tabular}

greatest amount of the variation $(27.1 \%)$ (forward selection sequential tests) (pseudo- $F_{11}=4.09, p=0.003$ ), followed by cod abundance $\left(17.0 \%\right.$; pseudo- $\left.F_{10}=3.03, p=0.018\right)$ and salinity $\left(10.9 \%\right.$; pseudo- $\left.F_{9}=2.17, p=0.05\right)$. While depth explained $7.0 \%$ of the variation in the scavenger community composition it did not explain a significant proportion of the variation. The predictor variables (fjord temperature, cod abundance, salinity and depth) explained $62.2 \%$ of the total variation in scavenger community composition (Table 3). The differences in scavenger community composition between the warmer and colder fjords was further explored with a PERMANOVA analysis and found to be significant (PERMANOVA, pseudo- $F_{1}=2.60, p=0.05$ ). Lysianassoid amphipods had the highest average abundance in the cold Svalbard fjords and contribution (SIMPER analysis; $51.0 \%$ ) to the dissimilarity between these and the other six fjords. This was followed by the ophiuroids, O. borealis (SIMPER analysis; $17.8 \%$ dissimilarity) and $O$. sericeum (SIMPER analysis; $6.1 \%$ dissimilarity). Pandalus sp., B. undatum, G. morhua and Nemertea sp. contributed to the highest average abundance of scavengers in the six Atlantic water influenced fjords. These taxa contributed 4.9, 3.7, 2.7 and $2.3 \%$ to the dissimilarity between these fjords and the scavenger community composition observed in the cold Svalbard fjords (Online Resource 3).

\section{Discussion}

This study represents one of the most comprehensive investigations of benthic invertebrate and demersal fish scavengers in high Arctic and Subarctic fjords to date. Results demonstrate a distinct difference in benthic scavenging assemblages between study fjords with differing hydrological and environmental conditions. In general, a greater number of taxa, from a greater range of scavenger groups (Fish, Crustaceans, Molluscs, Echinoderms, Nemertean and Polychaetes) were attracted to the bait in the fjords influenced by the relatively warm Atlantic Water, compared to fjords dominated by cold water masses. However, in these relatively warmer fjords there was a significantly lower abundance of scavengers and a lower removal rate of herring carcasses. In Rijpfjorden and Billefjorden, large abundances of specialized scavengers, such as lysianassoid amphipods and ophiuroids, quickly aggregated and consumed the herring bait.

The results presented here suggest that fjord temperature has a significant effect on the benthic scavenger community. The impact of temperature and duration of sea-ice-cover on the structure of benthic communities has previously been documented for infauna and epifauna in Svalbard fjords (Beuchel et al. 2006; Kędra et al. 2010; Kortsch et al. 2015; Meyer et al. 2015). Water temperature and depth were found to be major drivers of epibenthic megafaunal community composition between the warmer Atlantic Water influenced fjord Raudfjorden and the Arctic Water influenced fjord Rijpfjorden (Meyer et al. 2015). The study of Meyer et al. (2015) indicated a lower diversity and abundance of benthic megafauna species in Raudfjorden compared to Rijpfjorden. Our study on the scavenging fauna in 8 fjords also found lower species richness in Raudfjorden, but the relationship between diversity and temperature was not consistent as scavenger richness in Raudfjorden was lower than the other Atlantic Water fjords. Depth differences among stations had limited influence both on scavenger community abundance and composition in this study. The stark contrasts in scavenger communities between warm and cold Svalbard fjords, however, suggest that depth is unlikely to be the dominant factor here.

In consideration of our results and those of previous studies, it is clear that warmer temperatures have enabled more boreal species to exist in Atlantic Water influenced fjords. This process has contributed to a greater number and higher diversity of demersal fish and benthic invertebrate taxa identified in Atlantic Water fjords (Fossheim et al. 2015; Renaud et al. 2015). The boreal taxa observed in this study included G. morhua, H. platessoides, B. brosme, Pandalus sp., $H$. araneus, $P$. pubescens and $B$. undatum. Many of these boreal taxa are generalist feeders and can be described as predators, as well as facultative scavengers, as is common with many species attending carrion on the seafloor (Britton and Morton 1994; Ruxton and Houston 2004). This opportunistic strategy allows these scavengers to effectively utilize a range of food sources in the fjords, including carrion. Specialized scavengers are highly adapted to detect, locate and remove carrion (Ruxton and Houston 2004) and it is logical that these generalist boreal species can be less adapted to rapidly 
detect and utilize the bait. Low numbers of generalist scavenger taxa observed at the bait is likely to have led to lower scavenging rates in the warmer Atlantic Water influenced fjords. Rijpfjorden and Billefjorden are both influenced by colder winter-formed bottom water that is formed during ice formation and brine rejection and glacial meltwater in the innermost basins of the fjord, respectively. However, they supported a few highly specialized scavenger groups (lysianassoid amphipods and scavenging ophiuroids). These abundant taxa were able to rapidly detect carrion, aggregate in large numbers and remove carrion rapidly. The carrion removal rates in these cold Svalbard fjords were substantially higher than scavenging rates on mackerel in the southern Norwegian fjord Sognefjorden $\left(57.8 \mathrm{~g} \mathrm{~h}^{-1}\right.$ ) (Sweetman et al. 2014). Rates are, however, comparable to the speed at which fish bait was removed by scavenging Arctic amphipods in the Fram Straight (Arctic Ocean) (Premke et al. 2003). The rapid removal of carrion in the cold Svalbard fjords by benthic invertebrates can be considered as an adaptive trait to cope with seasonal differences in food availability in these periodically ice-covered fjords.

The distribution of Atlantic cod is dependent on water temperature (Sunby and Nakken 2008), and cod are now established in the warm Svalbard and northern Norwegian fjords studied, as confirmed by the trawl data from this study. The low bottom water temperatures in the two cold Svalbard fjords likely prevent Atlantic cod from achieving high densities. Atlantic cod feed on a wide range of benthic prey, including amphipods and echinoderms (Hüssy et al. 1997; Schwalme and Chouinard 1999; Link and Garrison 2002; Dalpadado and Bogstad 2004; Dalpadado et al. 2009). The increased abundance and distribution of Atlantic cod in the Arctic, therefore, has the potential to affect Arctic scavenger populations dominated by lysianassoid amphipods and Echinoderms. The lysianassoid amphipods play a key role in polar environments by transferring the energy contained in dead organic material to higher trophic levels (SainteMarie 1992; Jażdżewski et al. 1995). The role of amphipods in carrion consumption will be reduced if they have been removed by cod and their numbers diminished. This can lead to an alteration in pathways of energy transfer through the fjord food web or alternatively to other genera filling the role of scavengers. This study does not present a timeseries dataset on scavenger communities in the study fjords, but lysianassoids amphipods are also known to be highly abundant in the shallow waters of the warm Atlantic Water influenced Svalbard fjords; Adventfjorden (Nygård et al. 2009, 2010, 2012) Hornsund (Legeżyńska et al. 2000) and Kongsfjorden (Legeżyńska 2001). Baited traps, deployed in 2007 and 2008, also found that lysianassoid amphipods of the genus Anonyx dominated the scavenging fauna in Rijpfjorden (Nygård et al. 2012). Invertebrate scavengers (Crustaceans, Gastropods and Nemertean worms) were observed alongside fish fauna in the warm Svalbard fjords; however, their numbers were low $(<50$ at one time) compared to the cold Svalbard fjords. Invertebrate scavengers in warm Svalbard fjords appeared to have limited capacity to remove carrion and can also be subject to Atlantic cod predation, which provides a flow on energy from carrion to higher trophic levels.

In Kaldfjorden, Atlantic cod played a greater role in carrion removal and were responsible for high scavenging rates here, demonstrating that Atlantic cod can act as a scavenger, albeit a facultative one. In Kaldfjorden, Atlantic cod were observed to suck the bait into their mouths and to take large bites to remove the bait from the bag. Similar feeding behaviour of Atlantic cod has been observed (Jones 1978; Løkkeborg et al. 1998), and this behaviour can attract other cod (Brawn 1969). High scavenging rates from cod could also be connected to the concentrations of whelks that were attracted to and fed on the bait. In some cases, whelks appeared to have opened the herring carcasses, perhaps enhancing the odour plume and thereby attracting more Atlantic cod and other scavengers. Kaldfjorden experienced large influxes of Atlantic herring, and humpback whales (Megaptera novaeangliae) feeding on the herring, in the winters between 2012 and 2017 (Bakketeig et al. 2016; Zubiri 2017). Feeding by the whales caused the accumulation of many herring carcasses on the seafloor. The availability of fish carcasses on the seafloor in the winter from whale feeding and fishing discards are possible explanations for the adaptation of Atlantic cod in Kaldfjorden to scavenging.

Position within the fjord is known to affect benthic community composition through the influences of differences in sedimentation and food supply (Włodarska-Kowalczuk et al. 2005, 2012) but this was not studied here as an environmental parameter that could potentially effect scavenger community composition. In an effort to sample as many different fjords as possible, we were unable to replicate deployments along fjord gradients in fjords other than Rijpfjorden. The consistency of results here, however, suggests that the fjord basin selected (when more than one exists) may not have a strong influence on scavenger communities in many fjords. One possible exception could be the strongly glacially influenced Billefjorden, and, whereas scavenger community composition here differed from the other cold fjord (Rijpfjorden), scavenging rates were comparable despite the potentially strong influence of the glacier.

The Arctic is warming rapidly (Stocker et al. 2013; Sweetman et al. 2017) and there is a clear need to understand the implications of fjord temperature on scavenger communities and the potential impacts on their role on benthic fjord processes. Arctic and Subarctic fjords are experiencing both rapid warming and growing numbers of boreal species (such as Atlantic cod). It has been shown in this study that high Arctic and Subarctic fjords influenced by warmer Atlantic 
Water contain scavenger communities that are more diverse but of lower abundance than high Arctic fjords influenced by winter-formed bottom water. These colder water fjords support highly abundant scavenger assemblages of lysianassoid amphipods and ophiuroids that rapidly processed sunken carrion. This study demonstrates the potential impacts of warming Arctic temperatures, and associated shifts in predatory fish, on Arctic and Subarctic fjord benthic scavenging fauna and their role in benthic energy and nutrient cycling. These processes may indirectly alter scavenger efficiency in some fjords and potentially lead to an alteration in pathways of energy transfer through the fjord food webs.

Acknowledgements We gratefully acknowledge the crew of the RV Helmer Hanssen and RV Johan Hjort and the students of the UNIS Arctic Benthic Ecology course 2017 and Susan Dugan for assistance in the field. In addition we would like to acknowledge the support from Dr Tammy Horton (National Oceanography Centre, Southampton) with amphipod species identification. We would like to thank the three reviewers; Jan Marcin Weslawski, Alec E. Aitken and one anonymous reviewer for their constructive comments which helped to improve the manuscript. This research was funded by the Fram Centre Fjord and Coast Flagship project EFFECTS and the Norwegian Research Council project Jelly Farm (Grant No. 244572).

Author contributions KD, AKS, DOBJ, RPH, JB and PER conducted the field work and data collection, KD analysed the images and conducted the data analysis, AHST identified the amphipod specimens. All authors were involved in writing and editing various versions of the manuscript.

Funding Open Access funding provided by Institute Of Marine Research. This research was funded by the Fram Centre Fjord and Coast Flagship project EFFECTS and the Norwegian Research Council project Jelly Farm (Grant No. 244572).

Data availability All data included in this paper is available on Mendeley Data.

\section{Compliance with ethical standards}

Conflict of interest It is confirmed that as far as the authors are aware no conflict of interest exists regarding this manuscript.

Open Access This article is licensed under a Creative Commons Attribution 4.0 International License, which permits use, sharing, adaptation, distribution and reproduction in any medium or format, as long as you give appropriate credit to the original author(s) and the source, provide a link to the Creative Commons licence, and indicate if changes were made. The images or other third party material in this article are included in the article's Creative Commons licence, unless indicated otherwise in a credit line to the material. If material is not included in the article's Creative Commons licence and your intended use is not permitted by statutory regulation or exceeds the permitted use, you will need to obtain permission directly from the copyright holder. To view a copy of this licence, visit http://creativecommons.org/licenses/by/4.0/.

\section{References}

Bakketeig IE, Hauge M, Kvamme C, Sunnset BH, Toft KØ (2016) Havforskningsrapporten 2016. Fisken og havet 1:178-179

Berge J, Heggland K, Lønne ØL, Cottier F, Hop H, Gabrielsen GW, Nøttestad L, Misund OA (2015) First records of Atlantic mackerel (Scomber scombrus) from the Svalbard archipelago, Norway, with possible explanations for the extensions of its distribution. Arctic 68:54-61

Beuchel F, Gulliksen B, Carroll ML (2006) Long-term patterns of rocky bottom macrobenthic community structure in an Arctic fjord (Kongsfjorden, Svalbard) in relation to climate variability (1980-2003). J Mar Syst 63:35-48. https://doi.org/10.1016/j. jmarsys.2006.05.002

Beuchel F, Primicerio R, Lønne OJ, Gulliksen B, Birkely SR (2010) Counting and measuring epibenthic organisms from digital photographs: a semiautomated approach. Limnol Oceanogr 8:229-240. https://doi.org/10.4319/lom.2010.8.229

Brawn VM (1969) Feeding behaviour of cod (Gadus morhua). J Fish Res Board Can 26:583-596. https://doi.org/10.1139/f69-054

Britton JC, Morton B (1994) Marine carrion and scavengers. Oceanogr Mar Biol 32:369-434

Christiansen B, Diel-Christiansen S (1993) Respiration of Lysianassoid amphipods in a subarctic ford and some implications on their feeding ecology. Sarsia 78:9-15. https://doi.org/10.1080/00364 827.1993.10413516

Clarke KR, Gorley RN (2015) PRIMER v7: User Manual/Tutorial PRIMER-E: Plymouth

Cottier F, Tverberg V, Inall M, Svendsen H, Nilsen F, Griffiths C (2005) Water mass modification in an Arctic fjord through cross-shelf exchange: the seasonal hydrography of Kongsfjorden Svalbard. J Geophy Res. https://doi.org/10.1029/2004JC002757

Dalpadado P, Bogstad B (2004) Diet of juvenile cod (age 0-2) in the Barents Sea in relation to food availability and cod growth. Polar Biol 27:140-154. https://doi.org/10.1007/s00300-003-0561-5

Dalpadado P, Bogstad B, Eriksen E, Rey L (2009) Distribution and diet of 0-group cod (Gadus morhua) and haddock (Melanogrammus aeglefinus) in the Barents Sea in relation to food availability and temperature. Polar Biol 32:1583. https://doi.org/10.1007/s0030 0-009-0657-7

Fossheim M, Primicerio R, Johannesen E, Ingvaldsen RB, Aschan MM, Dolgov AV (2015) Recent warming leads to a rapid borealization of fish communities in the Arctic. Nat Climate Change 5:673-677. https://doi.org/10.1038/nclimate2647

Hop H et al (2019) Pelagic ecosystem characteristics across the Atlantic water boundary current from Rijpfjorden, Svalbard, to the Arctic Ocean during summer (2010-2014). Front Mar Sci 6:181. https ://doi.org/10.3389/fmars.2019.00181

Hüssy K, St John MA, Böttcher U (1997) Food resource utilization by juvenile Baltic cod Gadus morhua: a mechanism potentially influencing recruitment success at the demersal juvenile stage? Mar Ecol Prog Ser 155:199-208. https://doi.org/10.3354/meps155199

Jazdzewski K, Weslawski JM, De Broyer C (1995) A comparison of the amphipod faunal diversity in two polar fjords: Admiralty Bay, King George Island [Antarctic] and Hornsund, Spitsbergen [Arctic]. Polskie Archiwum Hydrobiologii 42:367-383

Jones R (1978) Estimates of the food consumption of haddock (Melanogrammus aeglefinus) and cod (Gadus morhua). ICES J Mar Sci 38:18-27. https://doi.org/10.1093/icesjms/38.1.18

Jones DOB, Bett BJ, Tyler PA (2007) Depth-related changes in the arctic epibenthic megafaunal assemblages of Kangerdlugssuaq, East Greenland. Mar Biol Res 3:191-204. https://doi. org/10.1080/17451000701455287 
Jones EM, Renner AH, Chierici M, Wiedmann I, Lødemel HH, Biuw M (2020) Seasonal dynamics of carbonate chemistry, nutrients and $\mathrm{CO}_{2}$ uptake in a sub-Arctic fjord. Elem Sci Anth 8(1):41

Kędra M, Włodarska-Kowalczuk M, Węsławski JM (2010) Decadal change in macrobenthic soft-bottom community structure in a high Arctic fjord (Kongsfjorden, Svalbard). Polar Biol 33:14322056. https://doi.org/10.1007/s00300-009-0679-1

King NJ, Bailey DM, Priede IG (2007) Role of scavengers in marine ecosystems: Introduction. Mar Ecol Prog Ser 350:75-178. https ://doi.org/10.3354/meps07186

Klages M, Vopel K, Bluhm H, Brey T, Soltwedel T, Arntz WE (2001) Deep-sea food falls: first observation of a natural event in the Arctic Ocean. Polar Biol 24:292-295. https://doi.org/10.1007/ s003000000199

Kortsch S, Primicerio R, Beuchel F, Renaud PE, Rodrigues J, Lønne OJ, Gulliksen B (2012) Climate-driven regime shifts in Arctic marine benthos. PNAS 109:14052-14057. https://doi. org/10.1073/pnas.1207509109

Kortsch S, Primicerio R, Fossheim M, Dolgov AV, Aschan M (2015) Climate change alters the structure of arctic marine food webs due to poleward shifts of boreal generalists. Proc R Soc B 282:20151546. https://doi.org/10.1098/rspb.2015.1546

Langlois T, Williams J, Monk J, Bouchet P, Currey L, Goetze J, Harasti D, Huveneers C, Lerodiaconou D, Malcolm H, Whitmarsh S (2018) Marine sampling field manual for benthic stereo BRUVS (Baited Remote Underwater Videos). In: Monk J (ed) Field manuals for marine sampling to monitor Australian waters. National Environmental Science Programme, Marine Biodiversity Hub, Canberra

Legeżyńska J (2001) Distribution pattern and feeding strategies of lyssianassoid amphipods in shallow waters of an Arctic fjord. Pol Polar Res 22:173-186

Legeżyńska J (2008) Food resource partitioning among Arctic sublittoral Lysianassoid amphipods in summer. Polar Biol 31:663670. https://doi.org/10.1007/s00300-008-0404-5

Legeżyńska J, Węsławski JM, Presler P (2000) Benthic scavengers collected by baited traps in the high Arctic. Polar Biol 23:539544. https://doi.org/10.1007/s003000000118

Link JS, Garrison LP (2002) Trophic ecology of Atlantic cod Gadus morhua on the northeast US continental shelf. Mar Ecol Prog Ser 227:109-123. https://doi.org/10.3354/meps227109

Løkkeborg S (1998) Feeding behaviour of cod, Gadus morhua: activity rhythm and chemically mediated food search. Anim Behav 56:371-378. https://doi.org/10.1006/anbe.1998.0772

Meyer KS, Sweetman AK, Young CM, Renaud PE (2015) Environmental factors structuring Arctic megabenthos-a case study from a shelf and two fjords. Front Mar Sci 2:22. https://doi. org/10.3389/fmars.2015.00022

Molina ÈJ, Silberberger MJ, Kokarev V, Reiss H (2019) Environmental drivers of benthic community structure in a deep sub-arctic fjord system. Estuar Coast Shelf Sci 225:106239. https://doi. org/10.1016/j.ecss.2019.05.021

Molis M, Beuchel F, Laudien J, Włodarska-Kowalczuk M, Buschbaum C (2019) Ecological drivers of and responses by Arctic Benthic Communities, with an emphasis on Kongsfjorden

Nygård H, Vihtakari M, Berge J (2009) Life history of Onisimus caricus (Amphipoda: Lysianassoidea) in a high Arctic fjord. Aquat Biol 5:63-74. https://doi.org/10.3354/ab00142

Nygård H, Wallenschu J, Camus L, Varpe Ø, Berge J (2010) Annual routines and life history of the amphipod Onisimus litoralis: seasonal growth, body composition and energy budget. Mar Ecol Prog Ser 417:115-126. https://doi.org/10.3354/meps08798

Nygård H, Berge J, Søreide JE, Vihtakari M, Falk-Petersen S (2012) The amphipod scavenging guild in two Arctic fjords: seasonal variations, abundance and trophic interactions. Aquat Biol 14:247-264. https://doi.org/10.3354/ab00394
Olsen E, Aanes S, Mehl S, Holst JC, Aglen A, Gjøsæter H (2009) Cod, haddock, saithe, herring, and capelin in the Barents Sea and adjacent waters: a review of the biological value of the area. ICES J Mar Sci 67:87-101. https://doi.org/10.1093/icesj $\mathrm{ms} / \mathrm{fsp} 229$

Premke K, Muyakshin S, Klages M, Wegner J (2003) Evidence for long-range chemoreceptive tracking of food odour in deepsea scavengers by scanning sonar data. J Exper Mar Biol Ecol 285:283-294. https://doi.org/10.1016/S0022-0981(02)00533-6

Premke K, Klages M, Arntz WE (2006) Aggregations of Arctic deepsea scavengers at large food falls: temporal distribution, consumption rates and population structure. Mar Ecol Prog Ser 325:121135. https://doi.org/10.3354/meps325121

R Core Team (2016) R: A language and environment for statistical computing. R Foundation for Statistical Computing; accessed 2018 January 17. http://www.R-project.org/

Renaud PE, Włodarska-Kowalczuk M, Trannum H, Holte B, Węsławski JM, Cochrane S, Dahle S, Gulliksen B (2007) Multidecadal stability of benthic community structure in a high-Arctic glacial fjord (van Mijenfjord, Spitsbergen). Polar Biol 30:295-305. https://doi. org/10.1007/s00300-006-0183-9

Renaud PE, Berge J, Varpe Ø, Lønne OJ, Nahrgang J, Ottesen C, Hallanger I (2012) Is the poleward expansion by Atlantic cod and haddock threatening native polar cod, Boreogadus saida? Polar Biol 35:401-412. https://doi.org/10.1007/s00300-011-1085-z

Renaud PE, Sejr MK, Bluhm BA, Sirenko B, Ellingsen IH (2015) The future of Arctic benthos: expansion, invasion, and biodiversity. Prog Oceanogr 139:244-257. https://doi.org/10.1016/j.pocea n.2015.07.007

Roy V, Iken K, Archambault P (2014) Environmental drivers of the Canadian Arctic megabenthic communities. PLoS ONE 9:e100900. https://doi.org/10.1371/journal.pone.0100900

Rudels B, Muench RD, Gunn J, Schauer U, Friedrich HJ (2000) Evolution of the Arctic Ocean boundary current north of the Siberian shelves. J Marine Syst 25:77-99. https://doi.org/10.1016/S0924 -7963(00)00009-9

Ruxton GD, Houston DC (2004) Energetic feasibility of an obligate marine scavenger. Mar Ecol Prog Ser 266:59-63. https://doi. org/10.3354/meps 266059

Sainte-Marie B (1992) Foraging of scavenging deep-sea Lysianassoid amphipods. Deep-sea food chains and the global carbon cycle. Springer, Dordrecht, pp 105-124

Schmid K, Reis-Filho JA, Harvey E, Giarrizzo T (2017) Baited remote underwater video as a promising nondestructive tool to assess fish assemblages in clearwater Amazonian rivers: testing the effect of bait and habitat type. Hydrobiology 784:93-109. https://doi. org/10.1007/s10750-016-2860-1

Schwalme K, Chouinard GA (1999) Seasonal dynamics in feeding, organ weights, and reproductive maturation of Atlantic cod (Gadus morhua) in the southern Gulf of St Lawrence. ICES J Mar Sci 56:303-319. https://doi.org/10.1006/jmsc.1999.0458

Svalbard. In: The Ecosystem of Kongsfjorden, Svalbard, Springer, Cham, pp. 423-481

Stocker TFet al (2013) IPCC. Climate Change 2013: The Physical Science Basis. Contribution of Working Group I to the Fifth Assessment Report of the Intergovernmental Panel on Climate Change. Cambridge University Press, Cambridge, United Kingdom and New York, NY, USA, 1-1535 pp

Sundby S, Nakken O (2008) Spatial shifts in spawning habitats of Arcto-Norwegian cod related to multidecadal climate oscillations and climate change. ICES J Mar Sci 65:953-962. https:// doi.org/10.1093/icesjms/fsn085

Svendsen H et al (2002) The physical environment of Kongsbergfjorden-Krossfjorden, an Arctic fjord system in Svalbard. Polar Res 21:133-166. https://doi.org/10.1111/j.1751-8369.2002.tb00072.x 
Sweetman AK, Smith CR, Dale T, Jones DO (2014) Rapid scavenging of jellyfish carcasses reveals the importance of gelatinous material to deep-sea food webs. Proc R Soc 281:20142210. https://doi. org/10.1098/rspb.2014.2210

Sweetman AK et al (2017) Major impacts of climate change on deepsea benthic ecosystems. Elem Sci Anth 5:2325-1026. https://doi. org/10.1525/elementa.203

Walkusz W, Storemark K, Skau T, Gannefors C, Lundberg M (2003) Zooplankton community structure; a comparison of fjords, open water and ice stations in the Svalbard area. Pol Polar Res 24:149-165

Walkusz W et al (2009) Seasonal and spatial changes in the zooplankton community of Kongsfjorden, Svalbard. Polar Res 28:254-281. https://doi.org/10.1111/j.1751-8369.2009.00107.x

Willis TJ, Babcock RC (2000) A baited underwater video system for the determination of relative density of carnivorous reef fish. Mar Fresh Res 51:755-763. https://doi.org/10.1071/MF00010

Włodarska-Kowalczuk M, Pearson TH (2004) Soft-bottom macrobenthic faunal associations and factors affecting species distributions in an Arctic glacial fjord (Kongsfjord, Spitsbergen). Polar Biol 27:155-167. https://doi.org/10.1007/s00300-003-0568-y
Włodarska-Kowalczuk M, Węsławski JM, Kotwicki L (1998) Spitsbergen glacial bays macrobenthos-a comparative study. Polar Biol 20:66-73. https://doi.org/10.1007/s003000050277

Włodarska-Kowalczuk M, Pearson TH, Kendall MA (2005) Benthic response to chronic natural physical disturbance by glacial sedimentation in an Arctic fjord. Mar Ecol Prog Ser 303:31-41. https ://doi.org/10.3354/meps303031

Włodarska-Kowalczuk M, Renaud PE, Węsławski JM, Cochrane SK, Denisenko SG (2012) Species diversity, functional complexity and rarity in Arctic fjordic versus open shelf benthic systems. Mar Ecol Prog Ser 463:73-87. https://doi.org/10.3354/meps09858

Yeh J, Drazen JC (2009) Depth zonation and bathymetric trends of deep-sea megafaunal scavengers of the Hawaiian Islands. Deep Sea Res 56:251-266. https://doi.org/10.1016/j.dsr.2008.08.005

Zubiri KO (2017) Diving behaviour of humpback whales feeding on overwintering herring in North-Norwegian fjords. Master's thesis, UiT Norges arktiske universitet, 2017

Publisher's Note Springer Nature remains neutral with regard to jurisdictional claims in published maps and institutional affiliations. 